ARTICLE

Received 13 Aug 2013 | Accepted 22 Nov 2013 | Published 9 Jan 2014

DOI: $10.1038 /$ ncomms 4004

OPEN

\title{
Structural analysis of human 2'-O-ribose methyltransferases involved in mRNA cap structure formation
}

\author{
Miroslaw Smietanski ${ }^{1,2}$, Maria Werner ${ }^{1}$, Elzbieta Purta ${ }^{1}$, Katarzyna H. Kaminska ${ }^{1}$, Janusz Stepinski ${ }^{3}$, \\ Edward Darzynkiewicz ${ }^{3,4}$, Marcin Nowotny ${ }^{2}$ \& Janusz M. Bujnicki, ${ }^{1,5}$
}

The $5^{\prime}$ cap of human messenger RNA contains $2^{\prime}$-O-methylation of the first and often second transcribed nucleotide that is important for its processing, translation and stability. Human enzymes that methylate these nucleotides, termed CMTr1 and CMTr2, respectively, have recently been identified. However, the structures of these enzymes and their mechanisms of action remain unknown. In the present study, we solve the crystal structures of the active CMTr1 catalytic domain in complex with a methyl group donor and a capped oligoribonucleotide, thereby revealing the mechanism of specific recognition of capped RNA. This mechanism differs significantly from viral enzymes, thus providing a framework for their specific targeting. Based on the crystal structure of CMTr1, a comparative model of the CMTr2 catalytic domain is generated. This model, together with mutational analysis, leads to the identification of residues involved in RNA and methyl group donor binding.

\footnotetext{
${ }^{1}$ Laboratory of Bioinformatics and Protein Engineering, International Institute of Molecular and Cell Biology in Warsaw, ul. ks. Trojdena 4, PL-02-109 Warsaw, Poland. ${ }^{2}$ Laboratory of Protein Structure, International Institute of Molecular and Cell Biology in Warsaw, ul. ks. Trojdena 4, PL-02-109 Warsaw, Poland. ${ }^{3}$ Division of Biophysics, Institute of Experimental Physics, Faculty of Physics, University of Warsaw, ul. Zwirki i Wigury 93, PL-02-089 Warsaw, Poland.

${ }^{4}$ Centre of New Technologies, University of Warsaw, ul. Zwirki i Wigury 93, PL-02-089 Warsaw, Poland. ${ }^{5}$ Laboratory of Bioinformatics, Institute of Molecular Biology and Biotechnology, Faculty of Biology, Adam Mickiewicz University, ul. Umultowska 89, PL-61-614 Poznan, Poland. Correspondence and requests for materials should be addressed to M.N. (email: mnowotny@iimcb.gov.pl) or to J.M.B. (email: iamb@genesilico.pl).
} 
M essenger RNAs (mRNAs) of all eukaryotic organisms and many viral RNAs possess a $5^{\prime}$ cap structure that consists of an $N^{7}$-methylguanosine $\left(\mathrm{m}^{7} \mathrm{G}\right)$ linked via an inverted $5^{\prime}-5^{\prime}$ triphosphate bridge to the $5^{\prime}$-terminal nucleoside of the transcript ${ }^{1}$. This cap0 structure is essential for the cell growth of Saccharomyces cerevisiae ${ }^{2}$ and survival of mammalian cells ${ }^{3}$. Cap0 is critical for mRNA interactions with many nuclear and cytoplasmic proteins and plays multiple roles in gene expression, including the enhancement of RNA stability, splicing, nucleocytoplasmic transport and translation initiation ${ }^{4,5}$. In higher eukaryotes, mRNA and small nuclear RNA (snRNA) $5^{\prime}$ ends are further modified by methylation of the ribose on the first and second transcribed nucleosides (that is, cap1 and cap2, respectively) ${ }^{6}$. In humans, cap0 and cap1 methylations are present on all mRNA molecules, whereas approximately half of the capped and polyadenylated RNA molecules contain cap2 methylation ${ }^{7}$. The U1, U2, U4 and U5 snRNAs are methylated at the first two positions ${ }^{8}$. Cap1 and cap2 methylations in U2 snRNA are required for spliceosomal $\mathrm{E}$ complex formation and consequently for efficient pre-mRNA splicing ${ }^{9}$.

Uncapped RNAs, such as nascent viral transcripts, may be detected as 'non-self' by the host cell, triggering an antiviral innate immune response through the production of interferons ${ }^{10}$. Therefore, many viruses that replicate in the cytoplasm of eukaryotes have evolved $2^{\prime}$-O-methyltransferases (2'-O-MTases) to autonomously modify their mRNAs. Although the RNA cap structures that originate from human and viral enzymes are identical, the structure and catalytic mechanisms of the virusencoded enzymes involved in the synthesis of the RNA cap structure are different from those of host cells. As a consequence, these pathogenic cap-forming enzymes are potential targets for antimicrobial drugs (as reviewed in ref. 11). Several potent inhibitors of viral cap1 MTases were recently identified, but their specificity and lack of toxicity (for example, the absence of interactions with human enzymes) remain to be established ${ }^{12}$.

To date, numerous high-resolution structures of viral RNA capping enzymes have been determined, but only a few of them represent complexes with RNA and shed light on specific cap recognition. This is partially because the availability of $5^{\prime}$-capped RNA substrates with a defined and appropriate length has remained an important bottleneck. A structure of vaccinia virus cap1 MTase VP39 has been solved as a ternary complex with $S$ adenosyl-L-homocysteine (SAH) and a capped RNA ${ }^{13}$. A number of structures of cap1 MTases from flaviviruses were determined with various cap analogues, revealing the structure of the capbinding pocket ${ }^{14,15}$. The development of compounds that inhibit viral cap1 MTases has been, however, greatly limited by the lack of structural information about the corresponding human enzymes that must not be inhibited by the virus-specific drugs. Genes that encode the human cap1 and cap2 MTases (that is, CMTr1 and CMTr2) have been only recently discovered ${ }^{16,17}$, enabling detailed biochemical and structural characterization of their products.

In the present study, we report crystal structures of an isolated, functionally active CMTr1 catalytic domain in several forms, including a complex with a capped oligoribonucleotide $\left(\mathrm{m}^{7}\right.$ GpppGAUC). Furthermore, a model of the CMTr2 catalytic domain bound to its target is presented. These structures reveal key differences in cap binding by human and viral enzymes, providing a framework for the search for viral cap MTase-specific inhibitors.

\section{Results}

Deletion analysis of cap MTases. To understand the contribution of individual domains to the function of CMTr1 and CMTr2,

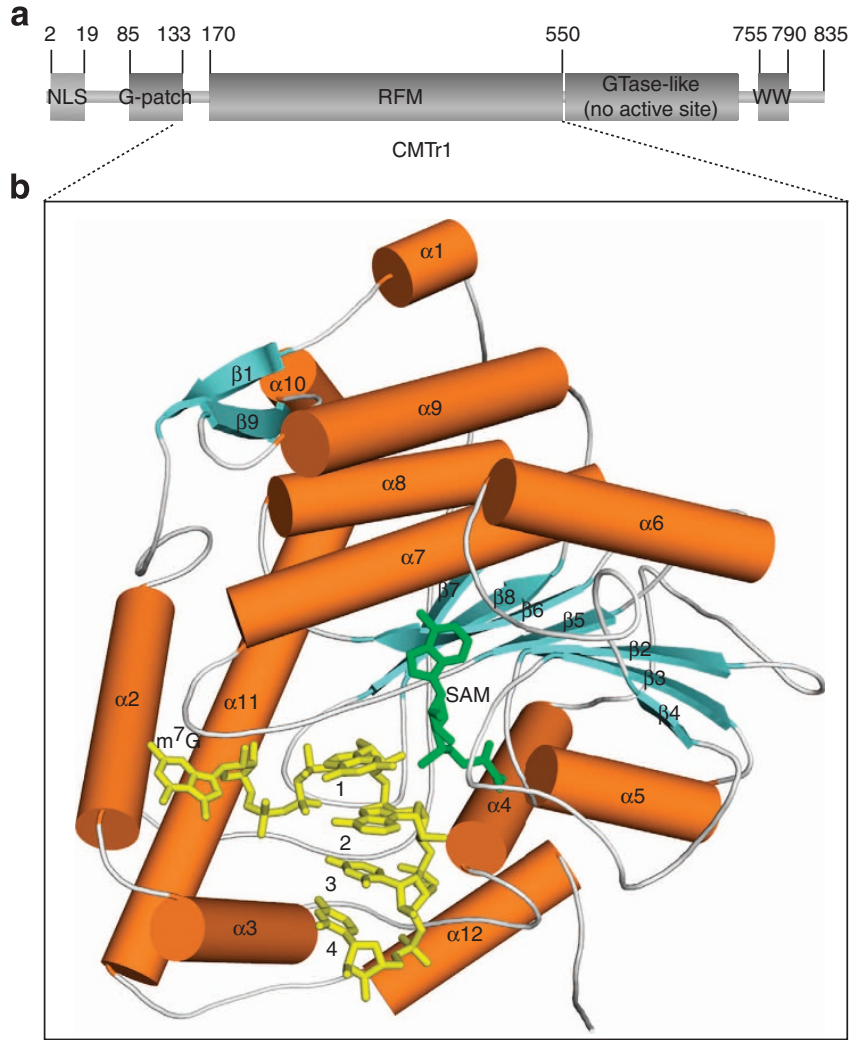

Figure 1 | Crystal structure of the catalytic MTase domain of CMTr1.

(a) Domain composition of full-length CMTr1. The dashed lines indicate the region of the protein $\left(\mathrm{CMTr}_{126-550}\right)$ present in the crystal structure. The domain boundaries are indicated with residue numbers. (b) Crystal structure of $\mathrm{CMTr}_{126-550}$ in complex with capped oligoribonucleotide ( $m^{7}$ GpppGAUC; coloured yellow) and SAM (green). Helices are shown in orange, $\beta$-strands are shown in blue and loops are shown in white.

we created deletion variants of each protein. For CMTr1, one of the variants $\left(\mathrm{CMTr} 1_{1-550}\right)$ contained the catalytic Rossmann-fold MTase (RFM) domain, G-patch and nuclear localization signal, and the other variant $\left(\mathrm{CMTr}_{550-835}\right)$ contained the remaining carboxy-terminal part that comprises the guanylyltransferase-like and WW domains (Fig. 1a). CMTr2 was also divided into two parts: the amino-terminal part with the catalytic RFM domain $\left(\mathrm{CMTr} 2_{1-430}\right)$ and the C-terminal part with the non-catalytic RFM domain $\left(\mathrm{CMTr} 2_{430-770}\right)$ (Fig. 2a). CMTr1 $1_{1-550}$ is able to bind a cap0-RNA substrate and methylate it, and the C-terminal guanylyltransferase-like domain of CMTr1 is not essential but contributes to the MTase activity of this protein (Fig. 3). The single domains of CMTr2 do not bind the substrate and do not exhibit any cap MTase activity alone or when mixed together as separately purified chains. Thus, CMTr2 requires both RFM domains in a single polypeptide chain for substrate binding and methylation.

CMTr1 catalytic domain structure. To elucidate the mechanism of cap recognition and methylation by CMTrl, we solved its crystal structure in complex with ligands. We expressed several deletion mutants in Escherichia coli and finally identified a stable CMTr1 variant that comprised a catalytic domain (residues 126-550; described in detail in the Supplementary Methods). The enzymatic activity of $\mathrm{CMTr}_{126-550}$ was confirmed in vitro (Supplementary Fig. S1); consequently, this protein variant was 


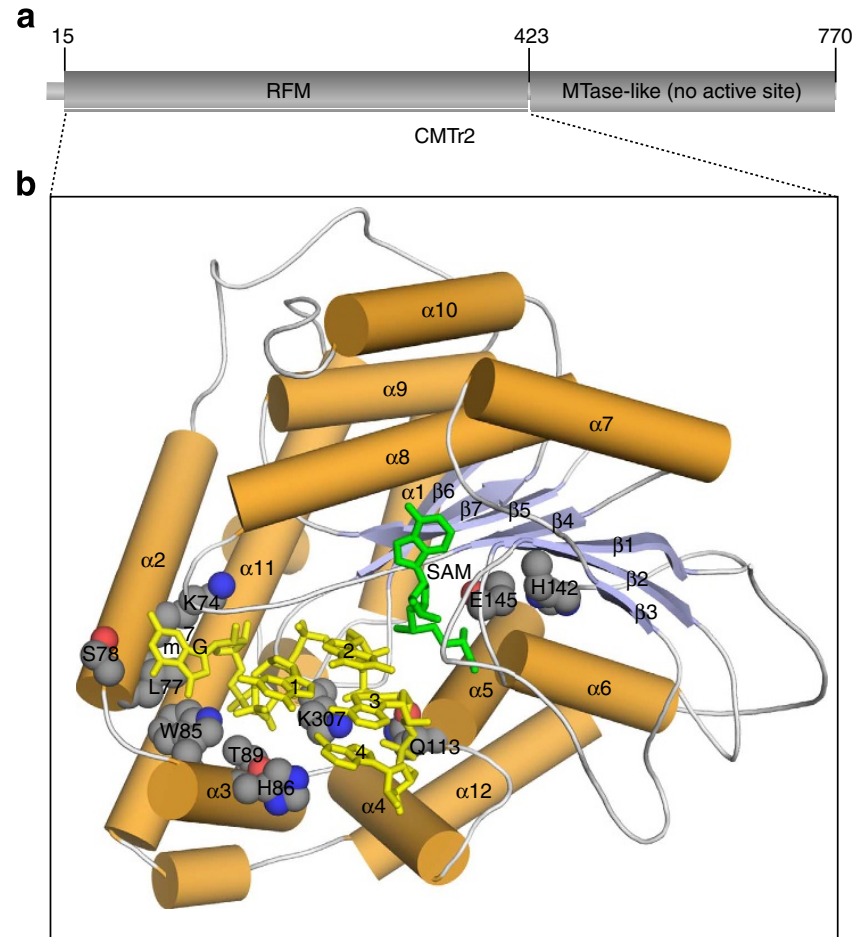

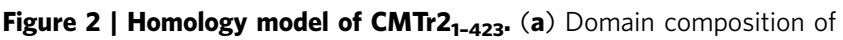
CMTr2. The dashed lines indicate a part of the protein that was modelled based on the CMTr1 $1_{126-550}$ crystal structure. The domain boundaries are indicated with residue numbers. (b) Homology model of the catalytic domain of CMTr2 in complex with capped oligoribonucleotide ( $\mathrm{m}^{7}$ GpppGGAA) and SAM. $\mathrm{m}^{7}$ GpppGGAA and SAM are coloured yellow and green, respectively. Helices are shown in orange, $\beta$-strands are shown in blue and loops are shown in white. Residues that were studied in directed mutagenesis experiments are shown in gray spheres.

used in the crystallization trials. We determined three crystal structures of the catalytic RFM domain of CMTr1: (i) an unliganded form at $2.35 \AA$ resolution, (ii) a ternary complex with cofactor $S$-adenosyl methionine (SAM) and an mRNA cap analogue $\left(\mathrm{m}^{7} \mathrm{GpppG}\right)$ at $1.9 \AA$ resolution and (iii) a complex with SAM and a capped oligoribonucleotide at $2.7 \AA$ resolution (Table 1). The three structures belong to space groups $I 422$ (i), $P 2_{1}$ (ii) and $P 1$ with two protein molecules in the asymmetric unit (iii) and together comprise four independent determinations of the protein structure. All four protein models are nearly identical and can be superimposed with a root mean squared deviation (r.m.s.d.) between $0.3 \AA$ (structure (ii) versus (iii), 367 pairs of $\mathrm{C}-\alpha$ atoms) and $0.7 \AA$ (structure (i) versus (iii), 336 pairs of $\mathrm{C}-\alpha$ atoms). The structural differences are limited to minor conformational changes of several loops upon substrate binding (Supplementary Fig. S2a). Complex structure (iii) with a capped oligoribonucleotide is shown in Fig. 1b.

The catalytic RFM domain of CMTr1 adopts the eponymous Rossmann-like fold ${ }^{18}$. The core of the domain comprises a characteristic $\beta$-sheet with seven strands surrounded by six $\alpha$ helices (that is, a structure conserved in nearly all members of the RFM superfamily). The peripheral extensions, both at the $\mathrm{N}$ - and C-termini, resemble the structures found in other cap-modifying MTases, including vaccinia virus VP39 protein that acts as a cap1 MTase $^{13}$, and a bifunctional cap0/cap1 MTase domain of flaviviruses ${ }^{19}$. In fact, viral cap1 MTases are the closest structural matches of the CMTr1 catalytic domain according to the DALI server ${ }^{20}$.
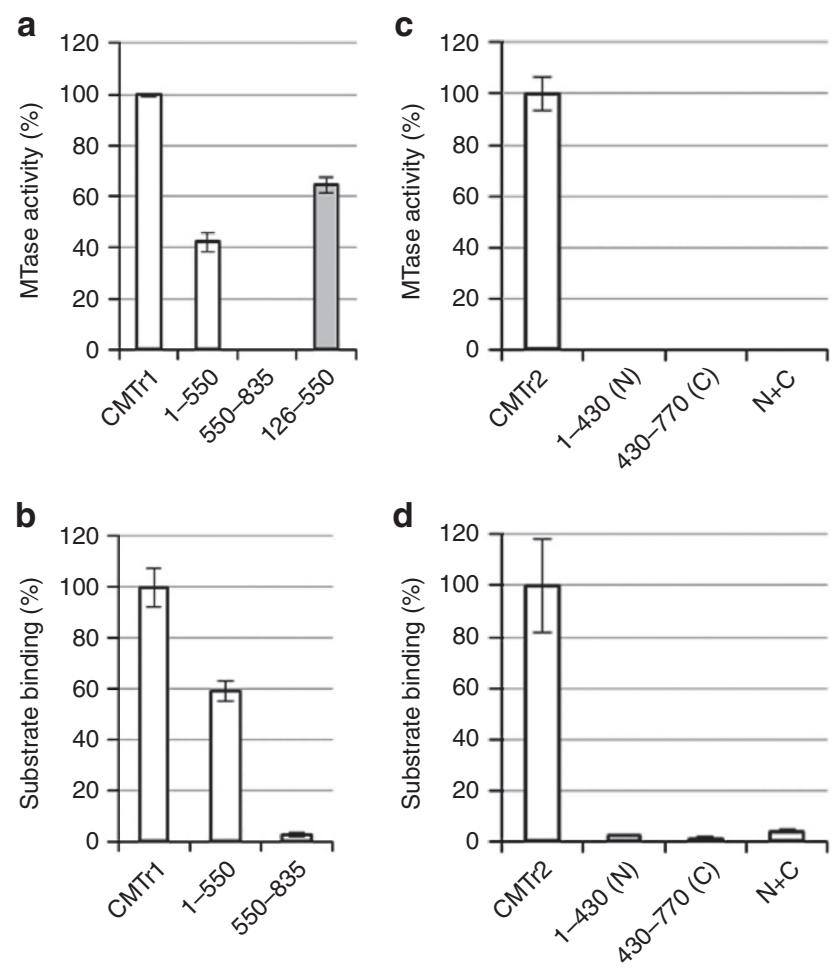

Figure 3 | Biochemical characterization of CMTr1 and CMTr2 and their fragments. The analysis was performed for full-length proteins and deletion variants of $\mathrm{CMTr} 1(\mathbf{a}, \mathbf{b})$ and $\mathrm{CMTr} 2(\mathbf{c}, \mathbf{d})$. The proteins were overexpressed in and isolated from HEK 293 cells (white bars) or E. coli (grey bar). Protein variant CMTr1 126-550 was expressed from crystallization construct. (a,c) MTase activity. In vitro transcribed RNA-GG molecules with a ${ }^{32} \mathrm{P}$-labelled cap0 (a) or cap01 (c) structure were incubated with the indicated enzymes in the presence of SAM. Product RNA was digested with nuclease P1 (a) or RNase T2 (c) and purified by phenol/chloroform extraction and ethanol precipitation. The digestion products were resolved on $21 \%$ polyacrylamide/ $8 \mathrm{M}$ urea gel and quantified after autoradiographic visualization. (b,d) Substrate binding. In vitro transcribed RNA-GG molecules with a ${ }^{32} \mathrm{P}$-labelled cap0 (b) or cap01 (d) structure were incubated with the indicated enzymes in the presence of SAH (the product of SAM demethylation) and uncapped, competitor RNA to detect specific substrate binding. After $30 \mathrm{~min}$ incubation, the samples were filtered through a nitrocellulose membrane and washed with reaction buffer. RNA bound to membrane-attached proteins was visualized by autoradiography and quantified. The signal from the negative control (that is, the sample with BAP protein) was subtracted from the signal from samples with cap MTases. The analyses were performed in triplicate. The relative activity/ binding compared with the full-length enzyme (set at 100\%) and s.d. values are shown.

Substrate and cofactor binding by the CMTr1 catalytic domain. In structures (ii) and (iii), we observed well-defined electron densities for the ligands (Supplementary Fig. S3). For both complexes, the SAM cofactor is bound in a deep pocket located at the edge of the central $\beta$-sheet between strands 2,3 and 4 (Fig. 1b). SAM binding is very similar to other RFM MTases, such as the NS5 protein from dengue virus ${ }^{21}$ and VP39 protein from vaccinia virus ${ }^{13}$.

In the structure of $C M T r 1_{126-550}$ in complex with SAM and a capped oligoribonucleotide substrate (structure (iii)), the nucleic acid adopts an $\mathrm{L}$ shape, with the methylated guanosine $\left(\mathrm{m}^{7} \mathrm{G}\right)$ accommodated in a deep pocket, and the methylatable nucleotide 1 located at the bend of the substrate molecule (Fig. 1b). The 
Table 1 | Statistics for SAD (SeMet) structure and molecular replacement.

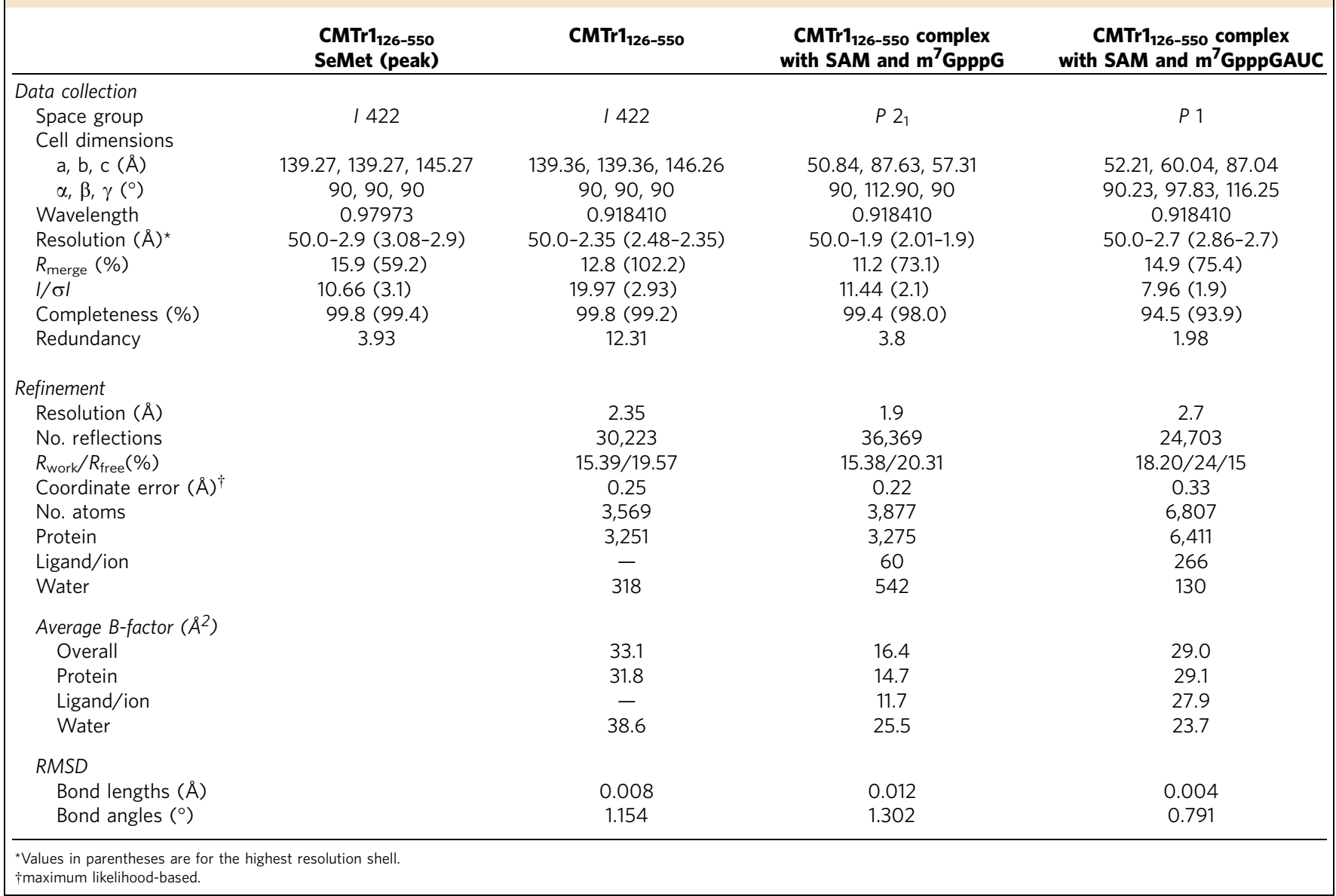

remainder of the mRNA exits from the binding site through a positively charged channel on the protein surface (Fig. 4a and Supplementary Fig. S4a,b). With the exception of the $\mathrm{m}^{7} \mathrm{G}$ residue, the interactions occur between the protein and phosphodiester backbone of the nucleic acid. The lack of contacts between the bases of the RNA and CMTr1 protein suggests that substrate binding and methylation are sequence-independent (Fig. 4c).

$\mathrm{m}^{7} \mathrm{G}$ binding and conformation are essentially identical between the structures of CMTr1 with the cap analogue (structure (ii)) and capped oligoribonucleotide (structure (iii)), but the position of $\gamma$-phosphate differs. This likely results from the fact that the first transcribed nucleotide of $\mathrm{m}^{7} \mathrm{GpppG}$ is disordered and not visible in the structure. The bottom of the $\mathrm{m}^{7} \mathrm{G}$-binding pocket is formed by the side chain of K203, and the amine group of this residue forms a hydrogen bond with the $2^{\prime}$ $\mathrm{OH}$ group of the ribose of $\mathrm{m}^{7} \mathrm{G}$ (Fig. 4b). The side chain of E373 forms a stacking interaction with the aromatic ring of $\mathrm{m}^{7} \mathrm{G}$. Additional interactions that stabilize the $\mathrm{m}^{7} \mathrm{G}$ part of the capped oligoribonucleotide are between D207 and $N 1$ of the $\mathrm{m}^{7} \mathrm{G}$ base and between N374 and N2 of the base. R218, Q376 and D439 interact with the triphosphate bridge. The importance of the $\mathrm{m}^{7} \mathrm{G}$ moiety for substrate binding and recognition is confirmed by the observation that RNA molecules without $5^{\prime}$ cap guanosine are not methylated by CMTr1, and human cap MTases generally appear to act only on a capped $5^{\prime}$ end of RNA (Supplementary Fig. S5).

In structure (iii), the key element that stabilizes the $\mathrm{m}^{7}$ GpppGAUC substrate is three guanidinium groups of arginine residues 218, 235 and 436, which all form a stacking sandwich that places a cluster of positive charges inside the turn of
L-shaped substrate molecule (Fig. 4c). The cluster interacts both directly and through water molecules with phosphate groups of the triphosphate linker and nucleotides 2 and 3 of the RNA. An additional residue that stabilizes the RNA backbone is K239, which, together with D364 and K404, forms the active site. The base of nucleotide 1 abuts the surface formed by the main chain of the protein (residues 366-368) and interacts with it through van der Waals contacts. The side chain amide group of N234 forms a hydrogen bond with the $2^{\prime}-\mathrm{OH}$ group of the ribose of the second transcribed nucleotide.

Model of the CMTr2 catalytic domain in complex with RNA. To facilitate comparisons between CMTr1 and CMTr2, we built a structural model of the CMTr2 $2_{1-423}$ catalytic domain by comparative modelling, using the CMTr $1_{126-550}$ structure as a template (Fig. 2b; see Methods for details). According to the model accuracy predictor MetaMQAP ${ }^{22}$, the predicted global root mean squared deviation of the modelled CMTr2 $2_{1-423}$ catalytic domain with respect to the (currently unknown) structure is $\sim 2.3 \AA$, which indicates good overall quality of the model. This estimation is based on $\mathrm{C}-\alpha$ positions; therefore, the atomic details of the model (for example, the conformations of the side chains) should be treated with caution. The RNA substrate of CMTr2 $2_{1-423}$ was also modelled using the comparative approach, with the CMTr1 $1_{126-550}$ substrate structure as the template (see Methods for details). We assumed that the regions that are conserved between $\mathrm{CMTr} 1_{126-550}$ and CMTr2 $2_{1-423}$ should interact with the functionally corresponding nucleotide residues $\left(\mathrm{m}^{7} \mathrm{G}\right.$ cap and the target ribose) in a very similar way (Supplementary Fig. S4c-e). 
a

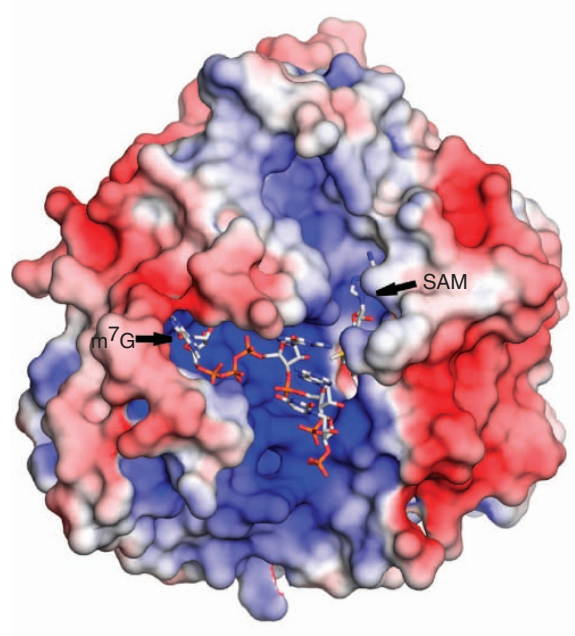

b

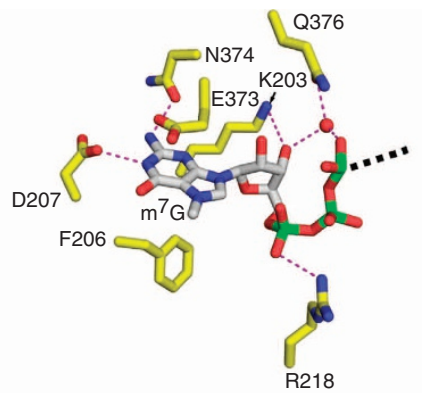

C

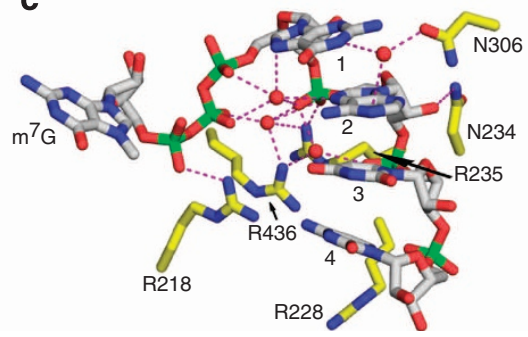

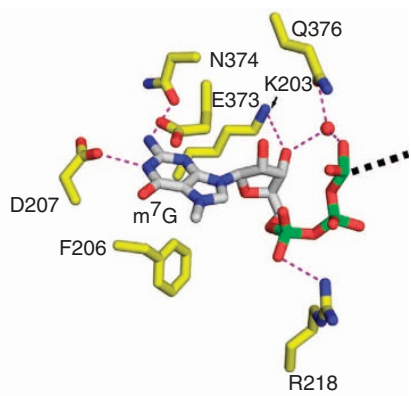

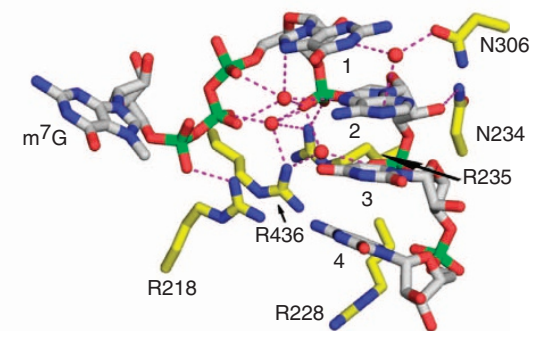

Figure 4 | Substrate and cofactor binding by $\mathbf{C M T r 1}_{\mathbf{1 2 6 - 5 5 0}}$ (a) Surface representation of CMTr1 $\mathbf{1}_{126-550}$ with electrostatic potential ( $\pm 5 \mathrm{kT} / \mathrm{e}$, red-negative; blue-positive). Capped oligoribonucleotide and SAM are shown in stick representation. (b) Stereo view of the interactions between the protein and $\mathrm{m}^{7} \mathrm{Gppp}$. The remainder of the RNA (four ribonucleotide residues) is omitted for clarity. (c) Stereo view of capped oligoribonucleotide binding. Water molecules that mediate the binding are shown as small red spheres.

Therefore, the modelling of CMTr2 $2_{1-423}$ substrate RNA involved introducing an insertion of one residue between the $5^{\prime}-5^{\prime}$ triphosphate and methylated ribose to reflect a register shift between the target of CMTr1 and CMTr2.

Substrate and cofactor binding by the CMTr2 catalytic domain. Comparisons of the experimentally determined structure of the ternary complex of the CMTr1 $1_{126-550}$ catalytic domain with its RNA substrate, with the corresponding model for the $\mathrm{CMTr} 2_{1-423}$ catalytic domain, reveal an essentially identical active site surrounded by variable residues (Supplementary Fig. S4e). The region of identity between the two enzymes spans most of the SAM-binding pocket, the entire active site (including the K-D-K catalytic triad), and the bottom of the cap guanosine-binding pocket. The differences are prominent in the region predicted to accommodate the $\mathrm{N} 1$ residue of the RNA substrate by $\mathrm{CMTr} 2_{1-}$ 423, which may explain the different specificities of CMTr1 and CMTr2 (methylation of RNA residue 1 or 2, respectively). The model of the CMTr2 $2_{1-423}$ catalytic domain is not sufficiently accurate to allow us to speculate about the atomic details of $N 1$ recognition. However, the modelled conformation of RNA agrees well with the experimental information. CMTr2 is able to methylate substrates, regardless of the presence of methylation of the cap guanosine or $N 1$ ribose $^{17}$. In our model, these methyl groups are exposed to the solvent and are not contacted by the protein. Furthermore, the N1 residue appears to interact with N3. During energy minimization, the N1 conformation converged to form a cis Hoogsteen-Hoogsteen base pair with N3. In alternative models, $N 1$ could be forced to flip by 180 degrees and interact with $N 3$ via the sugar edge. This feature of the model suggests that some base pair combinations in the $5^{\prime}$ end of capped RNAs may be more easily accommodated by the CMTr2 $2_{1-423}$ active site than others, providing a basis for the enzyme substrate specificity.

Mutagenesis analysis of CMTr1 and CMTr2. To validate the functional importance of amino-acid residues predicted to be critical for the substrate binding and enzymatic activity of human cap MTases, a mutagenesis analysis was performed. First, two variants of CMTr1 were prepared as controls to validate the method. The alanine substitution of K203 that directly interacts with RNA cap was expected to severely influence the binding and activity of the cap1 MTase. R228 is located in the vicinity of the capped mRNA substrate but does not interact with it, so we expected that R228A substitution would not affect activity or binding. We first analysed the binding and MTase activity of two control variants of CMTr1 with capped oligoribonucleotide (cap0-RNA-GG) as a substrate. As expected, the K203A substitution in CMTr1 strongly affects both the binding and activity of the enzyme, whereas R228A does not (Fig. 5), demonstrating that the method is able to discriminate between the residues that interact with substrate and those that do not.

We then used an analogous approach for CMTr2 studies. We selected 10 amino-acid residues located either in the conserved part of the active site (common to CMTr1 and CMTr2) or immediately outside of it (Fig. 2b). K74 in CMTr2, corresponding to K203 in CMTr1, forms the bottom of the cap-binding site, and L77 was predicted to form a side of the cap-binding site. Further selected residues included W85 (which interacts with L77 and the $5^{\prime}-5^{\prime}$ phosphate linker), T89 (which binds the $5^{\prime}-5^{\prime}$ phosphate linker), K307 (which interacts with the RNA backbone), H142 and E145 (which are in the SAM-binding motif), and S78, H86 and Q113 (which are located close to the RNA-binding site but do not form any specific interactions). These residues were individually substituted with alanine. As shown in Fig. 5, the substitutions of each of the selected residues of CMTr2 affect RNA binding. The catalytic activity of CMTr2 is less affected by the substitutions, but the decrease in activity correlates with the reduction of substrate binding. In agreement with the model, alanine substitutions K74A, L77A, W85A, T89A, K307A, H142A and E145A strongly affect both RNA binding and the catalytic activity of the enzyme. The fact that RNA binding is nearly abolished by the substitution of residues predicted to be important for SAM binding but are not in direct contact with RNA, suggests that cofactor binding by CMTr2 is essential for the 
a

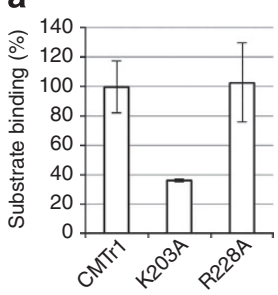

b

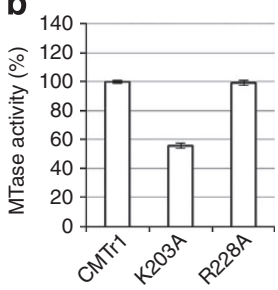

C

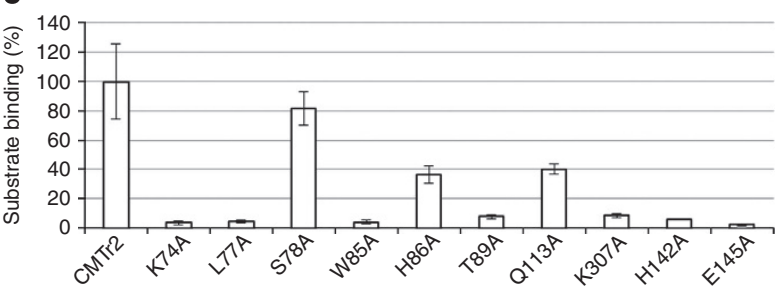

d

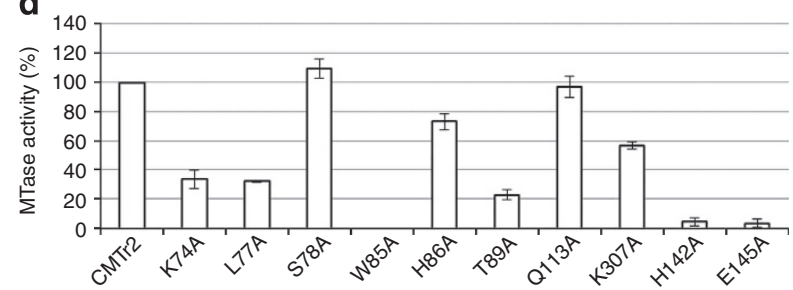

Figure 5 | MTase activity and RNA binding by CMTr1 and CMTr2 variants with single-residue substitutions. The analysis was performed for full-length wild type and single substitution variants of $\operatorname{CMTr} 1(\mathbf{a}, \mathbf{b})$ and $\mathrm{CMTr2}(\mathbf{c}, \mathbf{d}) .(\mathbf{a}, \mathbf{c})$ Effect of single amino-acid substitutions on MTase activity. In vitro transcribed RNA-GG molecules with a ${ }^{32}$ P-labelled cap0 (a) or cap01 (c) structure were incubated with the indicated enzymes in the presence of SAM. Product RNA was digested with nuclease P1 (a) or RNase T2 (c) and purified by phenol/chloroform extraction and ethanol precipitation. The digestion products were resolved on $21 \%$ polyacrylamide/8 $\mathrm{M}$ urea gel and quantified after autoradiographic visualization. (b,d) Effect of single amino-acid substitutions on substrate binding. In vitro transcribed RNA-GG molecules with a ${ }^{32}$ P-labelled cap0 (b) or cap01 (d) structure were incubated with the indicated enzymes in the presence of SAH. After 30-min incubation, the samples were filtered through a nitrocellulose membrane and washed with a reaction buffer. RNA bound to membrane-attached proteins was visualized by autoradiography and quantified. The signal from the negative control (the sample with the BAP protein) was subtracted from the signal from samples with cap MTases. The analyses were performed in triplicate. The relative activity/binding compared with the wild type enzyme (set at 100\%) and s.d. values are shown.

binding of RNA. The substitutions of residues S78, H86 and Q113 only mildly affect RNA binding and catalysis, so they are not essential for CMTr2 MTase activity. In conclusion, the results obtained for substituted proteins validated the accuracy of the homology model of CMTr2 and corroborated the residues involved in substrate binding.

\section{Discussion}

To date, structural information has only been available for viral 2 -O-ribose mRNA MTases from poxviruses and flaviviruses. Our structure of the human CMTr1 catalytic domain is the first example of a structure determined for a cellular enzyme of this type. It is also only the second enzyme of this group (the other is the VP39 protein form vaccinia virus; Protein Data Bank (PDB) ID: 1AV6 (ref. 13)) for which a structure with a bound capped oligoribonucleotide substrate is available.

The two most strongly conserved elements of the cellular, poxviral and flaviviral enzymes are the SAM-binding pocket determining the position of the methyl group donor and the active site determining the position of the target nucleoside $^{13,14,23}$. Surprisingly, however, cellular and viral enzymes interact with the guanosine cap in very different ways, although the cap-binding site is located in the same region of their structures (Fig. 6b). In vaccinia virus VP39 protein (for example, PDB ID:1AV6 (ref. 13)), guanosine is almost completely buried in a deep pocket sandwiched between two aromatic chains (Y22 and F180) and oriented with its Hoogsteen edge towards the binding pocket's floor (Fig. 6c). VP39 thereby senses the presence of the methyl group of $\mathrm{m}^{7} \mathrm{G}^{13,24}$. In structures of the flavivirus MTases bound to a cap analogue (for example, PDB ID: 2P40 (ref. 14) and $3 \mathrm{EMB}^{15}$ ), the $\mathrm{m}^{7} \mathrm{G}$ residue stacks with one aromatic residue (F24), but the binding site is open to the solvent, and interactions between the methyl group and protein are limited. In the structure of the human CMTr1 determined in the present study and in the theoretical model of CMTr2, $\mathrm{m}^{7} \mathrm{G}$ is bound in a deep pocket, but the sugar edge of the nucleoside residue is directed towards the pocket floor, with the methyl group exposed and involved in few interactions with the protein (Fig. 6d). Indeed, the activity of CMTr1 does not depend on the methylation of cap guanosine $e^{16,17,25}$. These differences between the human and viral enzymes are important because they provide the basis for the development of cap analogues that can block the viral cap MTases, without inhibiting the human enzymes. Ribose MTases acting on cap are extensively diverged and the complete understanding of evolutionary transitions between different binding modes will require determination of additional structures for other enzymes from this family ${ }^{17,26}$.

The common element of the human protein and flaviviral enzymes is the positively charged arginine cluster (formed by R218, R235 and R436 in CMTr1) that stabilizes the triphosphate bridge and phosphate backbone of RNA residues 1 and 2 (refs 23,27,28). Although the core of the catalytic domain of the human and vaccinia enzymes is highly similar (Fig. 6a), a prominent difference between the two structures is that the arginine cluster is missing in the latter. In fact, the backbone of the turn of the capped oligoribonucleotide molecule forms very few interactions in the vaccinia MTase-RNA complex.

In conclusion, we present the first structural characterization of cellular cap1 and cap2 MTases, revealing a new mode of RNA cap recognition. We also describe similarities and differences with viral enzymes, thus providing a framework for structure-based inhibitor design for those promising drug targets.

\section{Methods}

Eukaryotic overexpression of recombinant proteins. CMTr1, CMTr2 and bacterial alkaline phosphatase (BAP) proteins were overexpressed in HEK 293 cells (ATCC) using p3xFLAG-CMV-10 plasmid with an inserted open reading frame of CMTR1 (also known as KIAA0082, ISG95, FTSJD2 and HMTR1), CMTR2 (also known as AFT, FLJ11171, FTSJD1 and HMTR2), or BAP and jetPEI (Polyplus 
a
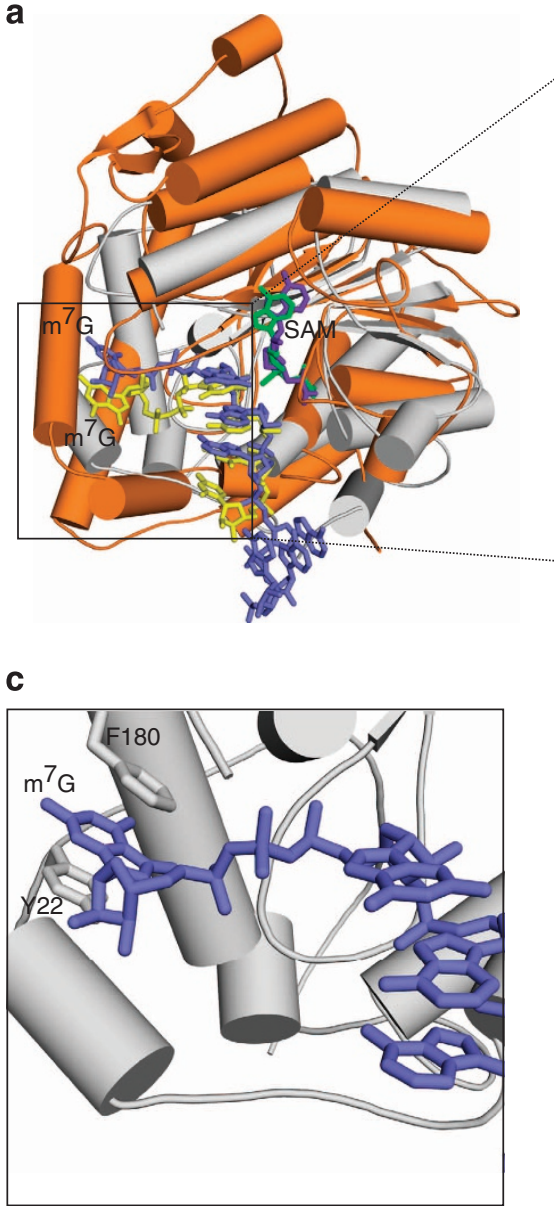

b

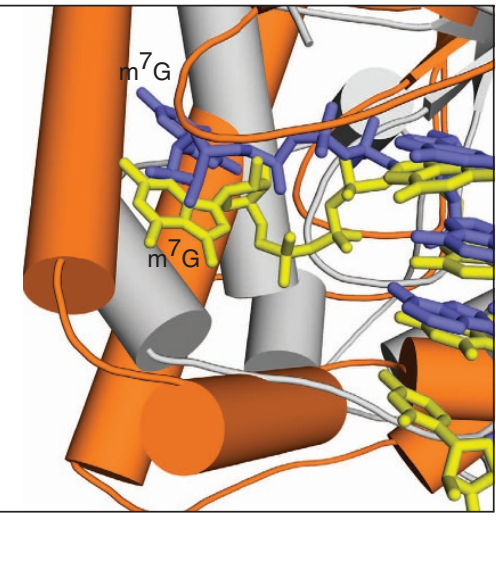

d

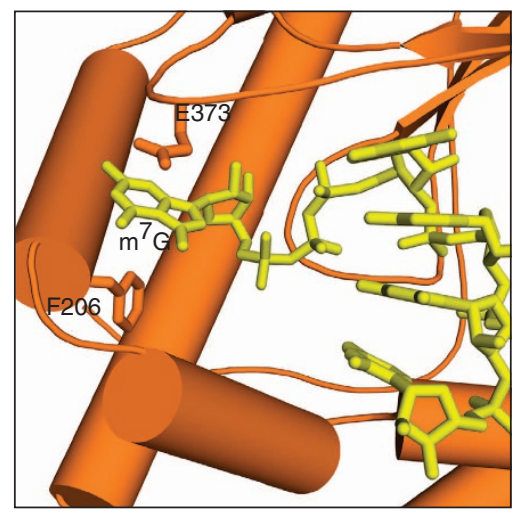

Figure 6 | Comparison of CMTr1 $\mathbf{1}_{\mathbf{1 2 6 - 5 5 0}}$ with the viral VP39 enzyme (a) Superimposition of CMTr1 $126-550$ substrate complex (orange) on VP39 (PDB ID: 1AV6). (grey) in complex with capped oligoribonucleotide (blue) and SAH (purple). The structures were superimposed using the C- $\alpha$ atoms from the central $\beta$-sheet. (b) Close-up view of the $\mathrm{m}^{7} \mathrm{G}$-binding pocket. For $\mathrm{CMTr} 1_{126-550}$, the protein is coloured orange, and $\mathrm{m}^{7} \mathrm{G}$ is coloured yellow. For $\mathrm{VP39}$, the protein is coloured grey, and $\mathrm{m}^{7} \mathrm{G}$ is coloured blue. (c,d) Close-up views of the interactions in $\mathrm{m}^{7} \mathrm{G}$ binding in VP39 MTase (c) and CMTr1 ${ }_{126-550}(\mathbf{d})$.

Transfection) transfection reagent ${ }^{17}$. For recombinant protein purification, cells were resuspended in lysis buffer $(50 \mathrm{mM}$ Tris- $\mathrm{HCl}(\mathrm{pH} 7.4), 150 \mathrm{mM} \mathrm{NaCl}, 1 \mathrm{mM}$ ethylenediaminetetraacetic acid (EDTA), $0.5 \%$ Triton X-100, protease inhibitor cocktail for use with mammalian cell and tissue extracts (Sigma)) and after $1 \mathrm{~h}$ of incubation centrifuged for $30 \mathrm{~min}$ at $20,000 \mathrm{~g}$. Supernatant was incubated with $25 \mu \mathrm{l}$ ANTI-FLAG M2 Affinity Gel (Sigma-Aldrich) with rotation overnight at $4{ }^{\circ} \mathrm{C}$ Beads were washed following manufacturer recommendations and resuspended in activity assay buffer. Protein samples were run in sodium dodecyl sulfatepolyacrylamide gel electrophoresis to measure the concentration of CMTr1 and BAP in each preparation using densitometry with the use of ImageQuantTL software (GE Healthcare). For CMTr2, the amount of the protein obtained was insufficient for densitometry measurements; therefore, the relative amounts of CMTr2 variants were examined by western blot using monoclonal anti-FLAG M2 antibody produced in mouse (dilution 1:5,000; Sigma-Aldrich) and anti-mouse IgGIRDye $800 \mathrm{CW}$ (dilution 1:10,000; LI-COR Biosciences) and analysed with Image Studio software (LI-COR Biosciences).

Variants of CMTR1 and CMTR2 were constructed using polymerase chain reaction (PCR). Single amino-acid substitutions were introduced by site-directed mutagenesis. DNA constructs for the expression of deletion variants that contained $\mathrm{N}$-terminal parts of the proteins were prepared by inserting a stop codon after residue 550 for CMTr1 and after residue 430 for CMTr2. The expression of the C-terminal domains was performed using constructs in which the regions that coded residues 2-549 for CMTr1 and 2-429 for CMTr2 were removed. The mutated genes were sequenced and found to contain only the desired changes. Sequences of all primers used in this study are listed in Supplementary Table S1.

Crystallography. All of the crystallization trials were performed using the vapor diffusion method at $18^{\circ} \mathrm{C}$ with a stock solution of $\mathrm{CMTr}_{126-550}$ at a $8-9 \mathrm{mg} \mathrm{ml}^{-1}$ concentration in a buffer that contained $100 \mathrm{mM} \mathrm{NaCl}, 30 \mathrm{mM}$ Tris- $\mathrm{HCl}(\mathrm{pH} 8.5)$, $10 \%$ glycerol, $0.5 \mathrm{mM}$ EDTA and $3 \mathrm{mM}$ dithiothreitol (DTT). Prior to crystallization, the protein was diluted with water to $4 \mathrm{mg} \mathrm{ml}^{-1}$ and mixed with a well solution at a $1: 1 \mathrm{v} / \mathrm{v}$ ratio.

Crystals of unliganded CMTr1 $1_{126-550}$ were obtained by co-crystallizing the protein with $\mathrm{m}^{7} \mathrm{GpppG}$ and SAM at a final concentration of $0.2 \mathrm{mM}$ for both ligands. The original condition for the crystallization of unliganded $\mathrm{CMTr}_{126-550}$ was identified in Index crystallization screen (Hampton Research) and contained $35 \%$ Tacsimate $(\mathrm{pH} 7.0)$. X-ray diffraction data were collected at beamline 14.1 of BESSY II on a Mar225 CCD detector at $100 \mathrm{~K}$. SeMet protein was crystallized with $\mathrm{m}^{7} \mathrm{GpppG}$ and SAM with both ligands at a concentration of $0.42 \mathrm{mM}$. The diffraction data from SeMet crystals were collected at $2.9 \AA$ resolution. The structure was solved using single-wavelength anomalous diffraction ${ }^{29}$ in Phenix AutoSol modul ${ }^{30}$ with default parameters. Selenium sites were found by HYSS, experimental phases were calculated in Phaser ${ }^{31}$ and density modification with solvent flattening was performed with Resolve. The figure-of-merit after phasing (before solvent modification) was 0.4 , and the resulting experimental electron density maps were well defined, allowing the tracing of a model that consisted of residues $141-544$ of the protein. The model was then refined against the native data set to $2.35 \AA$ resolution. Although $\mathrm{m}^{7} \mathrm{GpppG}$ and SAM were present in the crystallization mixture, their electron densities were not observed. We refer to this structure as 'unliganded' (structure (i)).

Different crystal forms of the complex of $\mathrm{CMTr}_{126-550}$ with $\mathrm{m}^{7} \mathrm{GpppG}$ and a methyl group donor were obtained by increasing the ligand concentrations in the co-crystallization mixture to 0.85 and $1.71 \mathrm{mM}$, respectively. They were grown in $30 \%$ PEG 3350, $100 \mathrm{mM}$ Bis-Tris (pH 6.5) and $100 \mathrm{mM} \mathrm{NaBr}$ as an additive. The structure was solved by molecular replacement using Phaser with a previously obtained unliganded structure as the search model and was refined to a resolution of $1.9 \AA$ (structure (ii); Table 1).

Crystals of the complex of CMTr1 $1_{126-550}$ with $\mathrm{m}^{7}$ GpppGAUC and SAM were obtained as a result co-crystallizing the protein with both ligands at concentrations of 0.85 and $1.71 \mathrm{mM}$, respectively. The crystals were grown in 30\% PEG 3350, $100 \mathrm{mM}$ Bis-Tris (pH 6.5) and $100 \mathrm{mM} \mathrm{NaBr}$ as an additive. The structure was solved by molecular replacement using Phaser with the structure of $C M \operatorname{Cr} 1_{126-550}$ 
complex with $\mathrm{m}^{7} \mathrm{GpppG}$ and SAM as a search model and refined to a resolution of $2.7 \AA$ (structure (iii); Table 1). The asymmetric unit contains two copies of the protein complex. In one copy, the electron densities for the capped oligoribonucleotide and three transcribed nucleotides are observed. In the second copy, all four nucleotides are visible (Supplementary Fig. S2b).

All of the data sets were processed using $\mathrm{XDS}^{32}$ with XDSAPP GUI ${ }^{33}$. The model building was performed in $\mathrm{Coot}^{34}$, and the structures were refined using phenix.refine. The following percentages of the residues were located in the allowed region of the Ramachandran plot: structure (i) $-98.7 \%$, structure (ii) $-99.8 \%$, and structure (iii) $-99.6 \%$. Simulated annealing omit maps were calculated using Phenix, and Pymol was used for structural analyses and the preparation of the structural figures (http://www.pymol.org; accessed 1 August 2013).

RNA substrate preparation. RNA-GG (a 63 nucleotide [nt] RNA oligonucleotide: 5'-GGGTAACGCTATTATTACAAAGCTCTTTTATGTAGTGTGCGTACCACG GTAGCAGGTACTGCG-3') was produced by in vitro transcription using AmpliScribe T7-Flash Transcription Kit and was subjected to capping reactions using vaccinia virus capping enzymes (Epicentre) ${ }^{17}$.

The capping reactions were performed according to the manufacturer's recommendations with the addition of $10 \mathrm{mCi}\left[\alpha^{-32} \mathrm{P}\right]$ GTP $\left(3,000 \mathrm{Ci} \mathrm{mmol}^{-1}\right.$; Hartman Analytic $\mathrm{GmbH}$ ). Unlabelled substrates were prepared following an analogous procedure with the use of $1 \mathrm{mM}$ guanosine triphosphate instead of its labelled counterpart.

The synthesis of $\mathrm{m}^{7} \mathrm{GpppGpApUpC}$ was performed by coupling the $5^{\prime}$ phosphorylated tetranucleotide pGpApUpC $(0.5 \mathrm{mg}$, ammonium salt; TriLink Biotechnologies) with 7-methylguanosine $5^{\prime}$-diphosphate imidazolide $(2.7 \mathrm{mg}$, prepared as described previously $\left.{ }^{35}\right)$ in $0.2 \mathrm{ml}$ of aqueous $0.2 \mathrm{M} \mathrm{N}$-ethylmorpholine/ $\mathrm{HCl}$ buffer $(\mathrm{pH} 7.0)$ that contained $\mathrm{MnSO}_{4} \cdot \mathrm{H}_{2} \mathrm{O}(6.4 \mathrm{mg})$ at room temperature for $24 \mathrm{~h}$. The resulting mixture was subjected to high-performance liquid chromatography preparative purification on an Agilent Technologies 1200 apparatus equipped with a Supelcosil LC-18-T reverse-phase column

$(4.6 \times 250 \mathrm{~mm})$ using a linear gradient of methanol as the mobile phase from 0 to $20 \%(\mathrm{v} / \mathrm{v})$ in $0.05 \mathrm{M}$ ammonium acetate ( $\mathrm{pH} 5.9)$ within $15 \mathrm{~min}$ at a flow rate of $1 \mathrm{ml} \mathrm{min}^{-1}$. Ultraviolet detection was performed at $260 \mathrm{~nm}$. The retention times were 10.1 and $10.4 \mathrm{~min}$ for the product and substrate, respectively. Appropriate eluates from 10 high-performance liquid chromatography runs were collected and lyophilized to give the product $(0.15 \mathrm{mg}$ ammonium salt). The predicted molecular mass for the free acid form is $1,742.0$, and the measured mass by high-resolution mass spectrometry (electrospray ionization) was $1,741.3$. The synthesized capped tetraribonucleotide was shown to be a substrate for CMTr1 MTase (Supplementary Fig. S6).

Methyltransferase assay. Methylation reactions with CMTr1 were carried out in $30 \mathrm{mM}$ Tris- $\mathrm{HCl}$ (pH 8.4), $150 \mathrm{mM} \mathrm{KCl,} 1 \mathrm{mM}$ EDTA, $10 \mathrm{mM}$ DTT, $100 \mathrm{mM}$ SAM, $10 \mathrm{U}$ Ribolock with $10 \mathrm{pmol}$ of purified enzyme and $0,25 \mathrm{pmol}$ of substrate RNA in a total volume of $20 \mu \mathrm{l}$. The reaction buffer for CMTr2 differed in $\mathrm{pH}(7.4)$ and $\mathrm{KCl}$ concentration $(50 \mathrm{mM})$. Reactions were carried out for $1 \mathrm{~h}$ at $37^{\circ} \mathrm{C}$. BAP protein was used as a negative control. The modified RNA was purified by phenol/ chloroform extraction and ethanol precipitation. The RNA was digested with either nuclease P1 (Sigma-Aldrich) or RNase T2 (MoBiTec GmbH). The digestion products were resolved on $21 \%$ polyacrylamide $/ 8 \mathrm{M}$ urea gel and visualized by autoradiography (Typhoon Trio, GE Healthcare). Quantitative analysis was performed using ImageQuant software (GE Healthcare).

Binding assay. Binding reactions with CMTr1 were performed in binding buffer (30 mM Tris-HCl (pH 8.4), $150 \mathrm{mM} \mathrm{KCl,} 1 \mathrm{mM}$ EDTA, $10 \mathrm{mM} \mathrm{DTT,} 10 \mu \mathrm{g} \mathrm{ml}^{-1}$ bovine serum albumin and $10 \mathrm{U}$ Ribolock) with $100 \mu \mathrm{M} \mathrm{SAH}, 5 \mathrm{pmol}$ of purified enzyme, $50 \mathrm{fmol}$ of ${ }^{32} \mathrm{P}$-labelled substrate RNA and $5 \mathrm{pmol}$ of unlabelled RNA without cap structure (competitor RNA) in a total volume of $20 \mu \mathrm{l}$. The reaction buffer for CMTr2 differed with regard to the $\mathrm{pH}(7.4)$ and $\mathrm{KCl}$ concentration $(50 \mathrm{mM})$. BAP protein was used as a negative control. The reactions were performed for $30 \mathrm{~min}$ at $37^{\circ} \mathrm{C}$ and filtered through a $0.2 \mu \mathrm{m}$ nitrocellulose membrane (GE Healthcare) using a Dot-Blot apparatus (Bio-Rad). Each well was washed with $400 \mu \mathrm{l}$ of the binding buffer. Dried membranes were exposed to a PhosphorImager screen, visualized by autoradiography and quantified using ImageQuant software.

Protein and RNA structure prediction and analysis. Protein structure prediction, including the identification of structured domains and disordered regions, the prediction of secondary structures and alignment with proteins of known structures, was performed via the GeneSilico web server ${ }^{36}$. Homology modelling of the CMTr2 catalytic domain structure was performed using the FRankenstein's monster approach ${ }^{37}$, in which a series of starting models based on alternative target-template alignments were generated, and a final hybrid model was constructed by splicing the potentially best folded fragments. For comparative modelling of the conserved core (residues 71-405 of CMTr2), Modeller ${ }^{38}$ 9v7 was used. The structure of the terminal regions of the CMTr2 catalytic domain with no clear match to the CMTr1 template (residues 1-70 and 406-423 of CMTr2) was predicted by de novo folding onto the precalculated homology model of the core with constraints on secondary structure using REFINER ${ }^{39}$. Protein three- dimensional model quality throughout the modelling process was assessed by MetaMQAP 22 , a programme that predicts the global accuracy of the protein structural model and deviations of individual residues from the positions of their counterparts in the true (unknown) structure. RNA comparative modelling was performed using ModeRNA ${ }^{40}$, followed by the optimization of local geometry and protein-RNA contacts with the Bio + version of the CHARMM force field using Hyperchem 8.0 (Hypercube). The mapping of the electrostatic potential on protein surfaces was done with Adaptive Poisson-Boltzmann Solver ${ }^{41}$. The mapping of sequence conservation onto the CMTr1 and CMTr2 catalytic domain structures was done using the ConSurf server ${ }^{42}$ with the JTT substitution matrix and Bayesian model for rate inference for the corresponding multiple sequence alignments obtained previously ${ }^{17}$. The multiple sequence alignment and model of the CMTr2 catalytic domain structure were also used to plan site-directed mutagenesis experiments. Structure database searches were performed with DALI.

Bacterial overexpression and protein purification. Synthetic CMTR1 gene was purchased from imaGenes GmbH (IMAGE ID 4944457) and amplified by PCR using primers that introduced $\mathrm{NcoI}$ and XhoI restriction sites that are compatible with the cloning sites of pETMM41 expression vector. After insertion into pETMM41, the CMTR1 gene was flanked on the $5^{\prime}$ end by a sequence that encoded HisTag and MBP. The latter was separated from the CMTR1 gene by a sequence that encoded the tobacco etch virus protease cleavage site. The full-length CMTr1 protein expressed in E. coli was insoluble. For the protein expressed in human embryonic kidney 293 cells, we could not obtain a sufficient amount of material for crystallization; therefore, we decided to work with the isolated RFM domain, which was predicted to be active based on analogous experiments with the Trypanosomal homolog ${ }^{43}$. To determine its boundaries, several N- and C-terminal deletion variants were designed, and constructs based on the pETMM41 expression vector were prepared using the QuikChange kit (Stratagene) or inside-out PCR. Protein variants were overexpressed in the ArcticExpress (DE3) E. coli strain and purified on nickel-charged resin (QIAGEN), and the activity of the soluble truncation variants was tested in the MTase assay (see below). First, we selected a protein variant with a C-terminal deletion of residues 551-835 (CMTr1 $\left.1_{1-550}\right)$. It was expressed in E. coli in a soluble form, but it was prone to degradation. We then used $C M T r 1_{1-550}$ in limited proteolysis experiments that showed that the protein form that was the most stable upon trypsin and chymotrypsin digestion had the same size as the spontaneous degradation product. According to our predictions with the MetaDisorder program ${ }^{44}$, the N-terminus of CMTr1 is rich in intrinsic disorder, which could make it susceptible to spontaneous proteolytic degradation. $\mathrm{N}$-terminal sequencing showed that $125 \mathrm{~N}$-terminal residues were absent. A deletion variant, $\mathrm{CMTr} 1_{126-550}$, was prepared and overexpressed as a fusion protein with MBP in the ArcticExpress (DE3) E. coli strain (Stratagene). CMTr1 $1_{126-550^{-}}$ MBP expression was induced with $0.3 \mathrm{mM}$ IPTG at an optical density of 0.8 , and the cells were further cultured for $24 \mathrm{~h}$ at $12{ }^{\circ} \mathrm{C}$. They were next lysed in buffer that contained $100 \mathrm{mM} \mathrm{NaCl}, 30 \mathrm{mM}$ Tris- $\mathrm{HCl}(\mathrm{pH} 8.5), 10 \%$ glycerol, $10 \mathrm{mM} \beta$ mercaptoethanol (2-ME), $5 \mathrm{mM}$ imidazole, $1 \mathrm{mg} \mathrm{ml}^{-1}$ lysozyme and a mixture of protease inhibitors. After $30 \mathrm{~min}$, the $\mathrm{NaCl}$ concentration was increased to $500 \mathrm{mM}$. The lysate was sonicated, centrifuged and clarified by filtration. The cleared lysate was then loaded on a $5 \mathrm{ml}$ HisTrap Crude column (GE Healthcare) previously equilibrated with $5 \mathrm{mM}$ imidazole, $500 \mathrm{mM} \mathrm{NaCl}, 30 \mathrm{mM}$ Tris- $\mathrm{HCl}(\mathrm{pH}$ 8.5 ), $10 \%$ glycerol and $10 \mathrm{mM} 2$-ME. CMTr1 $1_{126-550}$-MBP was eluted in a $40-$ $80 \mathrm{mM}$ imidazole gradient. Selected fractions were dialyzed overnight against a buffer that contained $30 \mathrm{mM} \mathrm{NaCl}, 30 \mathrm{mM}$ Tris- $\mathrm{HCl}$ (pH 8.5), $10 \%$ glycerol, $0.5 \mathrm{mM}$ EDTA and $3 \mathrm{mM}$ DTT. After this step, the dialyzed sample was loaded on the MonoQ column (GE Healthcare) previously equilibrated with dialysis buffer. The protein was eluted in a $250-280 \mathrm{mM} \mathrm{NaCl}$ gradient and digested overnight at $4^{\circ} \mathrm{C}$ using tobacco etch virus protease. The digested sample was loaded on a $5 \mathrm{ml}$ HisTrap Crude column equilibrated with $250-280 \mathrm{mM} \mathrm{NaCl}, 30 \mathrm{mM}$ Tris- $\mathrm{HCl}$ (pH 8.5), $10 \%$ glycerol, $0.5 \mathrm{mM}$ EDTA and $3 \mathrm{mM}$ DTT. The flow-through fraction was concentrated and purified on a Superdex 75 10/300GL gel filtration column (GE Healthcare). Selected fractions that contained $\mathrm{CMTr} 1_{126-550}$ were concentrated to $8.5 \mathrm{mg} \mathrm{ml}^{-1}$ and stored at $4{ }^{\circ} \mathrm{C}$ in a buffer that contained $100 \mathrm{mM} \mathrm{NaCl}, 30 \mathrm{mM}$ Tris- $\mathrm{HCl}$ ( $\mathrm{pH} 8.5$ ), $10 \%$ glycerol, $0.5 \mathrm{mM}$ EDTA and $3 \mathrm{mM}$ DTT. The SeMet derivative of the protein was expressed in minimal medium supplemented with SeMet and purified using the same protocol.

Analysis of methylation in vitro with the use of ${ }^{3} \mathrm{H}$-methyl-SAM. Methylation reactions with CMTrl were performed in reaction buffer $(30 \mathrm{mM}$ Tris- $\mathrm{HCl}(\mathrm{pH}$ 8.4), $150 \mathrm{mM} \mathrm{KCl}, 1 \mathrm{mM}$ EDTA, $10 \mathrm{mM}$ DTT and $10 \mathrm{U}$ Ribolock) that contained $1 \mu \mathrm{Ci}$ of [ ${ }^{3} \mathrm{H}$-methyl]-SAM, 50 pmoles of substrate and purified enzyme in a total volume of $20 \mu$ l. The reaction buffer for CMTr2 differed with regard to $\mathrm{pH}(7.4)$ and $\mathrm{KCl}$ concentration $(50 \mathrm{mM})$. For CMTr2, the cap01-RNA substrate was used instead of cap0 RNA. After 90 -min incubation at $37^{\circ} \mathrm{C}$, the enzyme was heatdenatured at $75^{\circ} \mathrm{C}$ for $10 \mathrm{~min}$. The samples were then loaded on DE $81 \mathrm{DEAE}$ paper (Whatmann). Free $\left[{ }^{3} \mathrm{H}\right.$ methyl] SAM was removed by washing the membrane with $50 \mathrm{mM}$ phosphate buffer ( $\mathrm{pH} 7.0)$. The dried membranes were transferred to scintillation vials with $1 \mathrm{ml}$ of liquid scintillator cocktail (Rotiszint eco plus, Roth). The amount of ${ }^{3} \mathrm{H}$-methyl group incorporation into the substrates bound to the membrane was measured using a Tri-Carb 2900 TR Liquid Scintillation Analyzer (Packard Bioscience; Supplementary Figs S5,S6). 


\section{References}

1. Muthukrishnan, S. et al. mRNA methylation and protein synthesis in extracts from embryos of brine shrimp, Artemia salina. J. Biol. Chem. 250, 9336-9341 (1975).

2. Mao, X., Schwer, B. \& Shuman, S. Yeast mRNA cap methyltransferase is a 50kilodalton protein encoded by an essential gene. Mol. Cell Biol. 15, 4167-4174 (1995).

3. Shafer, B., Chu, C. \& Shatkin, A. J. Human mRNA cap methyltransferase: alternative nuclear localization signal motifs ensure nuclear localization required for viability. Mol. Cell Biol. 25, 2644-2649 (2005).

4. Topisirovic, I., Svitkin, Y. V., Sonenberg, N. \& Shatkin, A. J. Cap and capbinding proteins in the control of gene expression. Wiley Interdiscip. Rev. RNA 2, 277-298 (2011).

5. Hocine, S., Singer, R. H. \& Grunwald, D. RNA processing and export. Cold Spring Harb. Perspect. Biol. 2, a000752 (2010).

6. Furuichi, Y. \& Shatkin, A. J. Viral and cellular mRNA capping: past and prospects. Adv. Virus Res. 55, 135-184 (2000).

7. Furuichi, Y. et al. Methylated, blocked 5 termini in HeLa cell mRNA. Proc. Natl Acad. Sci. USA 72, 1904-1908 (1975).

8. Massenet, S., Mougin, A. \& Branlant, C. The Modification And Editing Of RNA (Academic Press 201-227, 1998).

9. Donmez, G., Hartmuth, K. \& Luhrmann, R. Modified nucleotides at the $5^{\prime}$ end of human U2 snRNA are required for spliceosomal E-complex formation. RNA 10, 1925-1933 (2004).

10. Zust, R. et al. Ribose $2^{\prime}$-O-methylation provides a molecular signature for the distinction of self and non-self mRNA dependent on the RNA sensor Mda5. Nat. Immunol. 12, 137-143 (2011).

11. Ferron, F., Decroly, E., Selisko, B. \& Canard, B. The viral RNA capping machinery as a target for antiviral drugs. Antiviral Res. 96, 21-31 (2012).

12. Issur, M., Picard-Jean, F. \& Bisaillon, M. The RNA capping machinery as an anti-infective target. Wiley Interdiscip. Rev. RNA 2, 184-192 (2011).

13. Hodel, A. E., Gershon, P. D. \& Quiocho, F. A. Structural basis for sequencenonspecific recognition of $5^{\prime}$-capped mRNA by a cap-modifying enzyme. Mol. Cell 1, 443-447 (1998).

14. Egloff, M. P. et al. Structural and functional analysis of methylation and $5^{\prime}$-RNA sequence requirements of short capped RNAs by the methyltransferase domain of dengue virus NS5. J. Mol. Biol. 372, 723-736 (2007).

15. Bollati, M. et al. Recognition of RNA cap in the Wesselsbron virus NS5 methyltransferase domain: implications for RNA-capping mechanisms in Flavivirus. J. Mol. Biol. 385, 140-152 (2009).

16. Belanger, F., Stepinski, J., Darzynkiewicz, E. \& Pelletier, J. Characterization of hMTr1, a human cap1 2'O-ribose methyltransferase. J. Biol. Chem. 285, 33037-33044 (2010).

17. Werner, M. et al. $2^{\prime}$-O-ribose methylation of cap2 in human: function and evolution in a horizontally mobile family. Nucleic Acids Res. 39, 4756-4768 (2011).

18. Bujnicki, J. M. Comparison of protein structures reveals monophyletic origin of the AdoMet-dependent methyltransferase family and mechanistic convergence rather than recent differentiation of N4-cytosine and N6-adenine DNA methylation. In Silico Biol. 1, 175-182 (1999).

19. Assenberg, R. et al. Crystal structure of the Murray Valley encephalitis virus NS5 methyltransferase domain in complex with cap analogues. J. Gen. Virol. 88, 2228-2236 (2007).

20. Holm, L. \& Sander, C. Protein structure comparison by alignment of distance matrices. J. Mol. Biol. 233, 123-138 (1993).

21. Benarroch, D. et al. A structural basis for the inhibition of the NS5 dengue virus mRNA $2^{\prime}$-O-methyltransferase domain by ribavirin $5^{\prime}$-triphosphate. J. Biol. Chem. 279, 35638-35643 (2004).

22. Pawlowski, M., Gajda, M. J., Matlak, R. \& Bujnicki, J. M. MetaMQAP: a metaserver for the quality assessment of protein models. BMC Bioinformatics 9, 403 (2008).

23. Egloff, M. P., Benarroch, D., Selisko, B., Romette, J. L. \& Canard, B. An RNA cap (nucleoside-2'-O-)-methyltransferase in the flavivirus RNA polymerase NS5: crystal structure and functional characterization. EMBO J. 21, 2757-2768 (2002).

24. Hu, G., Gershon, P. D., Hodel, A. E. \& Quiocho, F. A. mRNA cap recognition: dominant role of enhanced stacking interactions between methylated bases and protein aromatic side chains. Proc. Natl Acad. Sci. USA 96, 7149-7154 (1999).

25. Langberg, S. R. \& Moss, B. Post-transcriptional modifications of mRNA. Purification and characterization of cap I and cap II RNA (nucleoside-2'-)methyltransferases from HeLa cells. J. Biol. Chem. 256, 10054-10060 (1981).

26. Feder, M., Pas, J., Wyrwicz, L. S. \& Bujnicki, J. M. Molecular phylogenetics of the RrmJ/fibrillarin superfamily of ribose 2'-O-methyltransferases. Gene 302, 129-138 (2003)

27. Mastrangelo, E. et al. Structural bases for substrate recognition and activity in Meaban virus nucleoside-2'-O-methyltransferase. Protein Sci. 16, 1133-1145 (2007)
28. Zhou, Y. et al. Structure and function of flavivirus NS5 methyltransferase. J. Virol. 81, 3891-3903 (2007).

29. Wang, B. C. Resolution of phase ambiguity in macromolecular crystallography. Methods Enzymol. 115, 90-112 (1985).

30. Adams, P. D. et al. PHENIX: a comprehensive Python-based system for macromolecular structure solution. Acta Crystallogr. D. Biol. Crystallogr. 66, 213-221 (2010).

31. McCoy, A. J. et al. Phaser crystallographic software. J. Appl. Crystallogr. 40, 658-674 (2007).

32. Kabsch, W. XDS. Acta Crystallogr. D. Biol. Crystallogr. 66, 125-132 (2010).

33. Krug, M., Weiss, M. S., Heinemann, U. \& Mueller, U. XDSAPP: a graphical user interface for the convenient processing of diffraction data using XDS. J. Appl. Cryst. 45, 568-572 (2012).

34. Emsley, P. \& Cowtan, K. Coot: model-building tools for molecular graphics. Acta Crystallogr. D. Biol. Crystallogr. 60, 2126-2132 (2004).

35. Sawai, H., Wakai, H. \& Nakamura-Ozaki, A. Synthesis and reactions of nucleoside $5^{\prime}$-diphosphate imidazolide. A nonenzymatic capping agent for $5^{\prime}$-monophosphorylated oligoribonucleotides in aqueous solution. J. Org. Chem. 64, 5836-5840 (1999).

36. Kurowski, M. A. \& Bujnicki, J. M. GeneSilico protein structure prediction metaserver. Nucleic Acids Res. 31, 3305-3307 (2003).

37. Kosinski, J. et al. A 'FRankenstein's monster' approach to comparative modeling: merging the finest fragments of Fold-Recognition models and iterative model refinement aided by 3D structure evaluation. Proteins 53(Suppl 6): 369-379 (2003)

38. Sali, A. \& Blundell, T. L. Comparative protein modelling by satisfaction of spatial restraints. J. Mol. Biol. 234, 779-815 (1993).

39. Boniecki, M., Rotkiewicz, P., Skolnick, J. \& Kolinski, A. Protein fragment reconstruction using various modeling techniques. J. Comput. Aided Mol. Des. 17, 725-738 (2003)

40. Rother, M., Rother, K., Puton, T. \& Bujnicki, J. M. ModeRNA: a tool for comparative modeling of RNA 3D structure. Nucleic Acids Res. 39, 4007-4022 (2011).

41. Baker, N. A., Sept, D., Joseph, S., Holst, M. J. \& McCammon, J. A. Electrostatics of nanosystems: application to microtubules and the ribosome. Proc. Natl Acad Sci. USA 98, 10037-10041 (2001)

42. Landau, M. et al. ConSurf 2005: the projection of evolutionary conservation scores of residues on protein structures. Nucleic Acids Res. 33, W299-W302 (2005).

43. Zamudio, J. R. et al. The 2'-O-ribose methyltransferase for cap 1 of spliced leader RNA and U1 small nuclear RNA in Trypanosoma brucei. Mol. Cell Biol. 27, 6084-6092 (2007).

44. Kozlowski, L. P. \& Bujnicki, J. M. MetaDisorder: a meta-server for the prediction of intrinsic disorder in proteins. BMC Bioinformatics 13, 11 (2012).

\section{Acknowledgements}

We would like to thank Iwona Ptasiewicz for excellent technical assistance, Michal Boniecki for help with the REFINER programme and the staff of beamline 14-1 at Berliner Elektronenspeicherung-Gesellschaft für Synchrotronstrahlung (BESSY) for assistance with data collection. This project was supported by the Polish Ministry of Science, the Polish National Science Centre (MNiSW and NCN; grant no. N301/425338 to J.M.B. and grants no. N301/096339 and UMO-2013/08/A/NZ1/00866 to E.D.) and the HHMI International Early Career Scientist Award to M.N. M.W. was also supported by the NCN (grant no. 2011/01/N/NZ1/00211 to M.W.) and by a START fellowship from the Foundation for Polish Science (FNP). J.M.B. and E.P. were also supported by FNP (grant no. TEAM/2009-4/2 to J.M.B.). K.H.K. was also supported by a START fellowship from the FNP. M.N. and J.M.B. were also supported by 'Ideas for Poland' fellowships from the FNP. Funding for open access charge: HHMI International Early Career Scientist Award to M.N.

\section{Author contributions}

The authors wish it to be known that the first two authors should be regarded as joint first authors. M.S., M.W., E.P., K.H.K., M.N. and J.M.B. designed the research. M.S., M.W., K.H.K. and J.M.B. performed the research. J.S. and E.D. contributed new reagents and analytic tools. M.S., M.W., E.P., K.H.K., M.N. and J.M.B. analysed the data. M.S., M.W., E.P., K.H.K., M.N. and J.M.B. wrote the paper.

\section{Additional information}

Accession codes: Atomic coordinates and structure factors of CMTr1 crystallographic structures have been deposited in the Protein Data Bank with accession codes 4 N48 (complex with $\mathrm{m}^{7} \mathrm{GpppGAUC}$ ), $4 \mathrm{~N} 49$ (complex with $\mathrm{m}^{7} \mathrm{GpppG}$ ) and $4 \mathrm{~N} 4 \mathrm{~A}$ (unliganded protein). Atomic coordinates of the CMTr2 model structure are available from http:// 
www.genesilico.pl/iamb/models/RNA.MTases/CMTr2/ and from http://www.figshare.com/articles/Structure_of_CMTr2_in_complex_with_capped_mRNA_theoretical_ model/840535.

Supplementary Information accompanies this paper at http://www.nature.com/nature communications

Competing financial interests: The authors declare no competing financial interests.
Reprints and permission information is available online at http://www.npg.nature.com/ reprintsandpermissions/

How to cite this article: Smietanski, M. et al. Structural analysis of human 2'-O-ribose methyltransferases involved in mRNA cap structure formation. Nat. Commun. 5:3004 doi: $10.1038 /$ ncomms4004 (2014).

(c) (i) (2) This work is licensed under a Creative Commons Attributioncc. No this license, visit http://creativecommons.org/licenses/by-nc-sa/3.0/ 